Jurnal DIALOGIKA Manajemen dan Administrasi

Homepage: https://ejurnal.unma.ac.id/index.php/dialogika

Vol. 1 No.2 April 2020, halaman: $86 \sim 95$

E-ISSN: 2720-9865, P-ISSN: 2716-3563

DOI : https://doi.org/10.31949/dialogika.v1i2.2172

\title{
PENGARUH KEMAMPUAN MANAJERIAL KEPALA SEKOLAH DAN BUDAYA ORGANISASI TERHADAP KINERJA GURU BERDAMPAK PADA MUTU LULUSAN
}

\author{
Anedi \\ Pascasarjana Universitas Majalengka, Jawa Barat, Indonesia \\ e-mail korespondensi : anedinedi@gmail.com
}

Disubmit Februari 2020 , Diterima Maret 2020 , Diterbitkan April 2020

Submitted February 2020 , Accepted March 2020 , Published April 2020

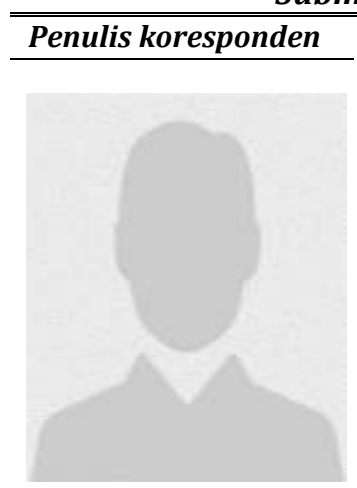

\begin{abstract}
This research is motivated by the phenomenon of low teacher performance which has an impact on the quality of graduates, presumably due to the low managerial ability of school principals and organizational culture. This study aims to determine: 1) the managerial ability of the principal; 2) organizational culture; 3) Teacher performance; 4) Quality of graduates; 5) The effect of principal managerial ability on teacher performance; 6) The influence of organizational culture on teacher performance; 7) The influence of principal managerial ability and organizational culture on teacher performance; 8) The effect of teacher performance on the quality of junior high school graduates in Majalengka Regency. Quantitative research methods with descriptive analysis techniques and verification. The descriptive method uses the calculation of frequency distribution, scoring and average value, while the verification method uses path analysis. The results of the descriptive study indicate that the principal's managerial abilities, organizational culture, teacher performance, and the quality of graduates are in good condition. The research results verificantly show that the principal managerial ability and organizational culture have a positive and significant effect on teacher performance either partially or simultaneously. Teacher performance has a positive and significant effect on the quality of graduates.
\end{abstract}

Keywords: Principal managerial ability, Organizational Culture, Teacher Performance, Quality of Graduates.

Jurnal DIALOGIKA

Manajemen dan Administrasi diterbitkan oleh Program Studi Administrasi Publik Pascarjana Universitas Majalengka

\begin{abstract}
Abstrak
Penelitian ini dilatarbelakangi fenomena rendahnya kinerja guru yang berdampak pada mutu lulusan, diduga disebabkan rendahnya kemampuan manajerial kepala sekolah dan budaya organisasi. Penelitian bertujuan untuk mengetahui : 1) Kemampuan manajerial kepala sekolah; 2) budaya organisasi; 3) Kinerja guru; 4) Mutu lulusan; 5) Pengaruh kumampuan manajerial kepala sekolah terhadap kinerja guru; 6) Pengaruh budaya organisasi terhadap kinerja guru; 7) Pengaruh kemampuan manajerial kepala sekolah dan budaya organisasi terhadap kinerja guru; 8) Pengaruh kinerja guru terhadap mutu lulusan SMP di Kabupaten Majalengka. Metode penelitian kuantitatif dengan teknik analisis deskriptif dan verifikatif. Metode deskriptif menggunakan perhitungan distribusi frekuensi, skoring dan nilai rata-rata, sedangkan metode verifikatif menggunakan analisis jalur. Hasil penelitian deskriptif menunjukkan bahwa kemampuan manajerial kepala sekolah, budaya organisasi, kinerja guru, dan mutu lulusan berada pada kondisi baik. Hasil penelitian secara verifikatif menunjukkan bahwa kemampuan manajerial kepala sekolah dan budaya organisasi berpengaruh positif dan signifikan terhadap kinerja guru baik secara parsial maupun simultan. Kinerja guru berpengaruh positif dan signifikan terhadap mutu lulusan.
\end{abstract}

Kata Kunci: Kemampuan manajerial Kepala Sekolah, Budaya Organisasi, Kinerja Guru, Mutu Lulusan. 


\section{PENDAHULUAN}

Dalam UU No 14 Tahun 2005 tentang Guru dan Dosen, pada Bab II, Pasal 4, dikemukakan bahwa "Kedudukan guru sebagai tenaga profesional sebagaimana dimaksud dalam Pasal 2 ayat (1) berfungsi untuk meningkatkan martabat dan peran guru sebagai agen pembelajaran berfungsi untuk meningkatkan mutu pendidikan nasional". Untuk menjalankan fungsi tersebut, guru memiliki beban yang wajib dilaksanakan sebaik-baiknya sesuai dengan apa yang tersurat dalam Bab IV, Pasal 35 yang dinyatakan bahwa "Beban kerja guru mencakup kegiatan pokok yaitu merencanakan pembelajaran, melaksanakan pembelajaran, menilai hasil pembelajaran, membimbing dan melatih peserta didik, serta melaksanakan tugas tambahan". Dengan demikian, apabila memperhatikan amanat undang-undang tersebut tugas utama guru adalah merencanakan pembelajaran, melaksanakan pembelajaran, menilai hasil pembelajaran, membimbing dan melatih serta melaksanakan tugas tambahan. Oleh karena itu, untuk mengetahui kadar kinerja guru salah satunya dapat dilihat dari pelaksanaan tugas-tugas tersebut. Berkenaan dengan hal ini, menurut Depdiknas, (2004:11), esensi kinerja guru tidak lain merupakan kemampuan guru dalam menunjukkan kecakapan atau kompetensi yang dimilikinya dalam dunia kerja sebenarnya. Dunia kerja guru yang sebenarnya adalah membelajarkan siswa dalam kegiatan pembelajaran di kelas.

Realita di lapangan, belum semua guru memenuhi aspek-aspek standar professsional, dengan indikator masalah antara lain : a) Belum semua guru melengkapi administrasi kelas sesuai standar; b) Belum semua guru mampu mengembangkan model pembelajaran yang relevan dengan materi; c) Belum semua guru menindaklanjuti hasil evaluasi dengan tepat; d) Belum semua guru dapat melakukan penelitian, terutama penelitian tindakan kelas ; dan e) Belum semua guru mampu membuat modul. Kondisi rendahnya kinerja guru salah satunya diduga sebagai akibat dari rendahnya kemampuan manajerial kepala sekolah. Karena, dilihat dari sisi manajerial pihak yang paling bertanggungjawab dalam upaya mempertahankan dan meningkatkan kinerja guru adalah atasan langsung (kepala sekolah) sebagai manajer.

Dari sudut pandang manajemen, kemampuan manajerial yang dibutuhkan dalam upaya meningkatkan kinerja guru menurut Dharma (2003:20), meliputi tiga hal, yaitu : “a) Manajemen pada tingkatan kepala dinas pendidikan; b) Manajemen pada tingkatan kepala sekolah; dan c) Manajemen pada tingkatan guru". Oleh karena itu, masuk akal apabila kepala sekolah turut bertanggungjawab atas peningkatan kinerja guru.

Selain kemampuan manajerial kepala sekolah, faktor lain yang diduga berpengaruh terhadap kinerja guru adalah budaya organisasi sekolah.Budaya organisasi merupakan persepsi bersama yang dianut oleh anggota-anggota organisasi itu dan menjadi suatu sistem dari makna bersama (Robbins, 2005). Dalam lembaga pendidikan (sekolah) yang telah menganut budaya organisasi kondusif, manakala berhadapan dengan masalah-masalah yang erat kaitannya dengan organisasi, tidak ada lagi penekanan saya melainkan menjadi kami. Dengan kata lain, kebersamaan akan muncul dan kerja tim akan terjalin dengan baik. Budaya organisasi penting untuk dijaga eksistensinya agar dapat diterapkan dalam berorganisasi.

Dengan memperhatikan uraian di atas, diasumsikan bahwa semakin baik kemampuan manajerial dan budaya organisasi sekolah akan semakin baik pula kinerja guru. Selanjutnya, dengan terciptanya kinerja guru yang baik pada gilirannya akan berdampak pada peningkatan mutu lulusan SMP. Lulusan merupakan out put dari proses pendidikan yang diselenggarakan di suatu lembaga pendidikan tertentu, sedangkan mutu lulusan merupakan out come yang diharapkan oleh semua pihak. Dengan kata lain, lulus saja tidak cukup, melainkan harus disertai mutu yang dapat diandalkan untuk proses selanjutnya. Dalam sistem pendidikan nasional di Indonesia, untuk menjamin lulusan yang bermutu telah terbit peraturan menteri tentang standar lulusan, yakni Permendiknas RI Nomor 23 tahun 
2006 tentang Standar Kompetensi Lulusan (SKL). Artinya, lulusan suatu lembaga pendidikan, termasuk SMP Negeri, dapat diakatakan bermutu apabila telah memenuhi standar sebagaimana dimaksud pada Peraturan Menteri tersebut.

Dalam rangka penelitian mengenai pengaruh kemampuan manajerial kepala sekolah dan budaya organisasi terhadap kinerja guru serta dampaknya terhadap mutu lulusan SMP Kabupaten Majalengka, kerangka pemikiran diilustrasikan berupa konstelasi antarvariabel di mana variabel bebas berpengaruh positip terhadap variabel terikat dan dapat dijabarkan sebagai berikut:

Variabel kemampuan manajerial kepala sekolah $\left(\mathrm{X}_{1}\right)$ berpengaruh positip terhadap variabel kinerja guru (Y), variabel Budaya organisasi $\left(\mathrm{X}_{2}\right)$ berpengaruh positip terhadap variaebl kinerja guru (Y), kemudian variabel $\mathrm{X}_{1}$ dan $\mathrm{X}_{2}$ berhubungan erat mempengaruhi variabel kinerja guru (Y), dan kinerja guru (Y) berdampak terhadap mutu lulusan SMP (Z). Kerangka pikir dari penelitian ini dapat digambarkan sebagai berikut :

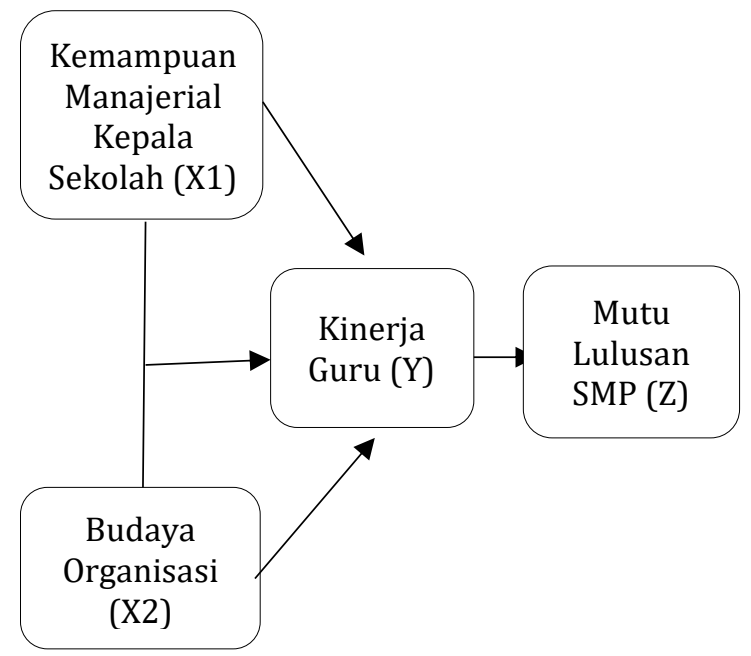

Gambar 1 Kerangka Pemikiran

Berdasarkan kerangka pemikiran tersebut di atas, diajukan hipotesis penelitian sebagai berikut :

1. Kemampuan manajerial kepala sekolah SMP diasumsikan baik.

2. Budaya organisasi diasumsikan baik.

3. Kinerja guru diasumsikan baik.

4. Mutu lulusan diasumsikan baik.
5. Terdapat pengaruh kemampuan manajerial kepala sekolah terhadap kinerja guru.

6. Terdapat pengaruh budaya organisasi terhadap kinerja guru.

7. Terdapat pengaruh kemampuan manajerial kepala sekolah dan budaya organisasi terhadap kinerja guru.

8. Terdapat pengaruh kinerja guru terhadap mutu lulusan SMP.

\section{METODE PENELITIAN}

Sugiyono (2014) mengemukakan bahwa "metode penelitian dapat diartikan sebagai cara ilmiah untuk mendapatkan data yang valid dengan tujuan dapat ditemukan, dikembangkan, dan dibuktikan, suatu pengetahuan tertentu sehingga dapat digunakan untuk memahami, memecahkan, dan mengantisispasi masalah" yang merupakan langkah penting untuk memecahkan masalah-masalah penelitian. Dengan menggunakan metode penelitian yang tepat, peneliti dapat memecahkan masalah-masalah penelitian yang akan bermanfaat dalam mengembangkan bidang ilmu yang didalami. Metode penelitian yang digunakan dalam penelitian ini yaitu penelitian kuantitatif dengan dengan analisis deskriptif dan verifikatif. Analisis deskriptif dilakukan dengan cara mencari informasi tentang gejala yang ada, kemudian didefinisikan dengan jelas sesuai dengan tujuan yang akan dicapai. Analisis verifikatif dilakukan dengan cara merencanakan pendekatan, mengumpulkan data sebagai bahan untuk membuat laporan serta melakukan pengujian hipotesis. Dalam penelitian ini peneliti ingin mengetahui keterkaitan antara kemampuan manajerial kepala sekolah dan budaya sekolah terhadap kinerja guru serta dampaknya pada mutu lulusan SMP. Variabel penelitian yang akan dikaji dalam penelitian ini dibagi menjadi dua variabel utama, yaitu variabel bebas (X) yang terdiri atas dua variabel, yaitu kemampuan manajerial kepala sekolah $\left(\mathrm{X}_{1}\right)$ dan budaya organisasi $\left(\mathrm{X}_{2}\right)$ dan variabel intervening $(\mathrm{Y})$ yaitu kinerja guru serta variabel terikat (Z) yaitu mutu lususan SMP. 
Dalam penelitian ini, populasi terdiri atas guru dan kepala sekolah SMP seKabupaten Majalengka sebanyak 341 orang. Penentuan jumlah sampel menggunakan rumus slovin dalam Husen Umar (2004:108). Dari hasil perhitungan didapat sampel sebanyak 100 orang. Pengumpulan data primer menggunakan kuesioner berupa sejumlah pernyataan yang diajukan kepada responden dengan maksud mengumpulkan data langsung dari sumber utama. Dalam setiap variabel, disusun instrumen berdasarkan yang dijabarkan pada butir-butir kuesioner yang dilengkapi dengan alternatif jawaban dengan skala likert. Untuk menjamin validitas dan reliabilitas instrumen, dilakukan uji validitas dan reliabilitas. Kemudian, data yang diperoleh diolah dan dianalisis menggunakan analisis jalur (path analysis). Analisis utama yang dilakukan adalah untuk menguji konstruk jalur apakah teruji secara empiris atau tidak. Analisis selanjutnya dilakukan untuk mencari pengaruh langsung dan pengaruh tidak langsung bagi variabel bebas terhadap variabel terikat. Di samping itu, analisis jalur tipe analisis multivariate untuk mempelajari efek-efek langsung dan tidak langsung dari sejumlah variabel yang dihipotesiskan sebagai variabel yang mempengaruhi terhadap variabel lainnya sebagai variabel akibat. Hubungan kausalitas antar variabel sejak perumusan masalah telah dibentuk dengan model sesuai teori yang melandasinya. Proses pengolahan data, menggunakan bantuan komputer program SPSS for Window versi 20.0.

\section{HASIL PENELITIAN DAN PEMBAHASAN}

Sesuai dengan rancangan awal penelitian ini, bahwa analisis data menggunakan dua macam, yaitu analisis deskriptif dan verifikatif.

Analisis deskriptif dilakukan dengan cara mengolah dan menganalisis data hasil jawaban responden atas kuesioner yang disebarkan. Cara yang ditempuh diawali dengan menghitung nilai kumulatif, kemudian menghitung persentase, dan menetapkan kriteria penilaian dengan tabel interpretasi data untuk menentukan kualitas. Setelah data diolah, diperoleh hasil deskriptif sebagai berikut.

Variabel kemampuan manajerial kepala sekolah, diperoleh rata-rata skor 384 $(69,60 \%)$ dalam kategori baik. Persentase terbesar pada indikator "penyusunan perencanaan sekolah" mencapai 80,80\%, sedangkan terendah pada indikator mengelola perubahan dan mengelola sistem informasi, masing-masing 55,80\% dan $56,20 \%$. Aspek inilah yang merupakan temuan empiris pada variabel kemampuan manajerial kepala sekolah.

Variabel budaya organisasi diperoleh rata-rata skor $363,83 \quad(72,77 \%)$ dalam kategori baik. Persentase terbesar pada indikator "terdapat anjuran motivasi" mencapai $86,60 \%$, sedangkan terendah pada indikator kenaikan gaji berdasarkan prestasi dan keberanian warga sekolah dalam mengajukan kritik, masing-masing $59,80 \%$ dan 63,60\%. Aspek inilah yang merupakan temuan empiris pada variabel budaya organisasi.

Variabel kinerja guru, diperoleh ratarata skor 353,83 $(70,69 \%)$ dalam kategori baik. Persentase terbesar pada indikator "guru mampu merencanakan pembelajaran" mencapai $82,00 \%$, sedangkan terendah pada indikator guru mampu melibatkan siswa dalam pembelajaran, hanya mencapai $65,80 \%$. Aspek inilah yang merupakan temuan empiris pada variabel kinerja guru.

Variabel mutu lulusan, diperoleh ratarata skor 363,19 $(72,64 \%)$ dalam kategori baik. Persentase terbesar pada indikator "lulusan menghargai perbedaan pendapat" mencapai 83,80\%, sedangkan terendah pada indikator lulusan belum sepenuhnya dapat menerapkan nilai-nilai kebersamaan dalam kehidupan bermasyarakat, berbangsa, dan bernegara, hanya mencapai 58,60\%. Aspek inilah yang merupakan temuan empiris pada variabel mutu lulusan.

Analisis verifikatif dilakukan dengan cara mengolah dan menganalisis data hasil jawaban responden atas kuesioner yang disebarkan dengan menggunakan pendekatan statistik parametrik. Metode yang digunakan sebagai jawaban atas rumusan masalah di atas, pada penelitian ini 
diselesaikan dengan analisis jalur yang merupakan pengembangan korelasi yang diurai menjadi beberapa penafsiran atas akibat yang ditimbulkannya. Selain itu, sifat analisis jalur memiliki kedekatan dengan regresi berganda. Dengan kata lain, regresi berganda merupakan bentuk khusus dari proses analisis data dengan analisis jalur. Namun demikian, perlu dijelaskan bahwa dalam penelitian ini menggunakan analisis jalur, dengan alasan memiliki keunggulan jika dibandingkan dengan analisis regresi dan analisis korelasi. Secara konsep, kelebihan analisis jalur adalah dapat diketahuinya derajat hubungan antarvariabel dependen, pengaruh langsung, pengaruh tidak langsung, total pengaruh dan pengaruh gabungan (simultan) serta pengujian hipotesis yang diukur secara parsial dan simultan.

Pada penelitian ini diteliti tentang pengaruh kemampuan manajerial kepala sekolah dan budaya organisasi terhadap kinerja guru yang memiliki dampak pada mutu lulusan SMP. Penyelesaian analisis jalur pada penelitian ini menggunakan bantuan software SPSS Versi 20.0 Secara diagram hasil analisis jalur digambarkan sebagai berikut :

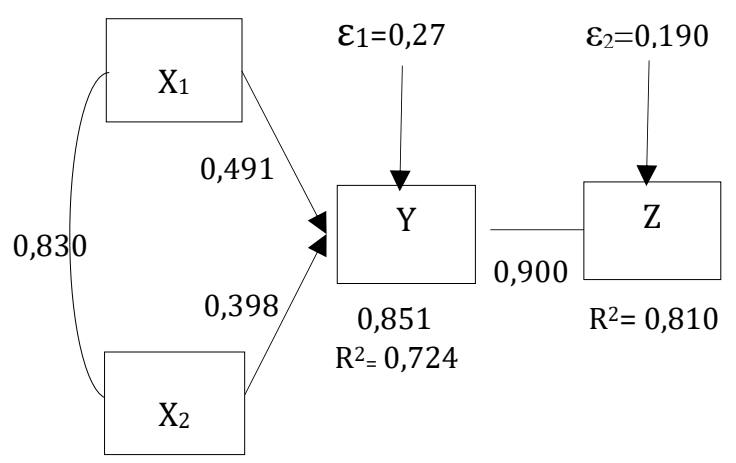

Gambar 2 Hasil Struktur Analisis Jalur

Dari data yang tertera pada gambar 2, diketahui bahwa hasil struktur analisis jalur di atas terdiri dari nilai koefisien korelasi dan koefisien jalur. Analisis terhadap koefisien korelasi diperoleh bahwa nilai koefisien korelasi antara kemampuan manajerial kepala sekolah dan budaya organisasi dengan nilai korelasi sebesar 0,830. Nilai tersebut mengindikasikan bahwa kedua variabel memiliki hubungan yang kuat. Selanjutnya, pada analisis jalur akan diteliti mengenai kontribusi pengaruh dari masing-masing konstruk dalam model analisis jalur. Gambar di atas, menunjukkan bahwa analisis jalur terbentuk oleh dua konstruk yaitu konstruk I adalah variabel kemampuan manajerial kepala sekolah dan budaya organisasi terhadap kinerja guru dan konstruk II adalah variabel kinerja guru terhadap mutu lulusan SMP. Hasil analisis terhadap koefisien jalur untuk konstruk I didapat bahwa variabel kemampuan manajerial kepala sekolah memiliki nilai koefisien jalur tertinggi bila dibandingkan dengan variabel budaya organisasi. Koefisien jalur untuk variabel kemampuan manajerial kepala sekolah terhadap kinerja guru sebesar 0,491. Sedangkan koefisien jalur untuk variabel budaya organisasi terhadap kinerja guru hanya sebesar 0,398. Adapun nilai koefisien jalur untuk konstruk II antara variabel kinerja guru dengan mutu lulusan SMP memiliki nilai koefisien jalur sebesar 0,900. Dilihat dari hasil analisis koefisien jalur ternyata variabel kinerja guru memiliki hasil nilai koefisien jalur sangat signifikan terhadap mutu lulusan SMP se-Kabupaten Majalengka.

Analisis kontribusi pengaruh untuk konstruk I yaitu pengaruh yang diberikan oleh variabel kemampuan manajerial kepala sekolah dan budaya organisasi terhadap kinerja guru yang diukur secara parsial dan simultan dapat diuraikan sebagai berikut :

Pengaruh langsung dari variabel kemampuan manajerial kepala sekolah terhadap kinerja guru dengan nilai koefisien jalur sebesar 0,491; maka nilai pengaruh langsungnya sebesar $(0,491)^{2} \times 100 \%=$ $24,11 \%$. Pengaruh langsung dari variabel budaya organisasi terhadap kinerja guru dengan nilai koefisien jalur sebesar $(0,1584)^{2} \times 100 \%=15,84 \%$.

Pengaruh tidak langsung dari variabel kemampuan manajerial kepala sekolah terhadap kinerja guru melalui budaya organisasi sebesar $(0,491 \times 0,830 \times 0,398) \times$ $100 \%=16,22 \%$.

Pengaruh tidak langsung dari variabel budaya organisasi terhadap kinerja guru guru melalui kemampuan manajerial kepala 
sekolah sebesar $(0,398 \times 0,830 \times 0,491) \times$ $100 \%=16,22 \%$.

Total pengaruh dari variabel kemampuan manajerial kepala sekolah terhadap kinerja guru baik secara langsung maupun tidak langsung sebesar 40,34\%.

Total pengaruh variabel budaya organisasi terhadap kinerja guru baik secara langsung maupun tidak langsung sebesar $32,06 \%$.

Total pengaruh secara simultan yang diberikan oleh variabel kemampuan manajerial kepala sekolah dan budaya organisasi terhadap kinerja guru sebesar $40,34 \%+32,06 \%=72,40 \%$.

Kemampuan manajerial kepala sekolah erat kaitannya dengan semua upaya penelitian yang tertuju pada semua aspek yang merupakan faktor penentu keberhasilan pencapaian tujuan pendidikan, salah satunya menghasilkan lulusan yang bermutu. Dengan mengetahui kondisi kemampuan manajerial kepala sekolah kaitannya dengan pendidikan secara rinci dan akurat, dapat diketahui dengan tepat apa yang diperlukan untuk meningkatkan mutu lulusan. Kemampuan manajerial idealnya melihat hal-hal masih lemah atau kurang lengkap untuk dapat diupayakan aga menjadi lebih baik dan mampu menemukan mana yang telah baik untuk dapat ditingkatkan agar menjadi semakin baik. Di samping itu, dalam proses manajerial kepala sekolah, bukan terfokus pada unsur pengelolaan semata, melainkan diperlukan juga kemampuan membaca peluang dan mewaspadai ancaman yang bersifat eksternal untuk mengantisipasi hambatan dalam intensal sekolah dan mengambil manfaat dari peluang yang ada untuk kemajuan sekolah. Dalam hal ini, erat kaitannya dengan kompetensi kepala sekolah yang dituntut untuk memiliki kompetensi kewirausahaan.

Budaya organisasi erat kaitannya dengan penerapan nilai-nilai moral dalam kehidupan sehari-hari, terutama di lingkungan sekolah. Nilai-nilai tersebut berupa pembentuk sikap dan perilaku dan penampilan fisik, termasuk tata cara berpakaian, sikap hormat terhadap tamu, saling menghargai sesama warga sekolah, bahkan tercermin juga dalam lingkungan sekolah yang bersih, hijau, aman, dan nyaman. Di samping itu, nilai-nilai yang dipertahankan di lingkungan sekolah akan menjadi ciri khas bagi orang-orang yang terlibat di dalamnya sekaligus merupakan indentitas sekolah secara kelembagaan yang dapat membedakannya dengan sekolah lain. Maka dalam hal ini, terkait dengan kemampuan manajerial, kepala sekolah dituntut untuk peka terhadap perubahan yang terjadi kaitannya dengan budaya organisasi sekolah. Hal-hal yang sudah dianggap baik harus dipertahankan, apabila masih ada yang lemah atau kurang baik hendaknya segera diperbaiki.

Dari hasil pengujian hipotesis
membuktikan bahwa kemampuan
manajerial kepala sekolah dan budaya
organisasi berpengaruh positif dan
signifikan terhadap kinerja guru. Artinya,
semakin baik kemampuan manajerial
kepala sekolah dan semakin kondusif
budaya organisasi sekolah, maka kinerja
guru akan semakin tinggi karena
dipengaruhi dua faktor yang paling dominan
serta satu sama lain terdapat saling
hubungan. Kemampuan manajerial kepala
sekolah memungkinkan terciptanya budaya
organisasi yang kondusif, sebaliknya budaya
organisasi yang kondusif akan mendorong
kepala sekolah untuk mengelola sekolah
dengan lebih baik karena mendapat
dukungan dari semua warga sekolah yang
sadar nilai.

Hasil penelitian dan analisis data selanjutnya menunjukkan bahwa kinerja guru berpengaruh signifikan terhadap mutu lulusan SMP. Baik secara normative maupun logika, kinerja guru merupakan faktor kunci penentu keberhasilan pencapaian tujuan pendidikan di sekolah, khususnya dalam meningkatkan mutu lulusan. Oleh karena itu, mutu lulusan sangat bergantung kepada kinerja guru. Dengan demikian, semakin baik kinerja guru, maka mutu lulusan akan semakin meningkat.

\section{KESIMPULAN}

Hasil analisis deskriptif menunjukkan bahwa menurut persepsi responden tentang kemampuan manajerial kepala sekolah 
secara umum dikategorikan baik. Namun terdapat kelemahan dalam hal mengelola perubahan, maka temuan empiris ini dapat dijadikan petunjuk bagi kepala sekolah SMP bagaimana cara mempertahankan dan meningkatkan kemampuan manajerial dengan cara memperbaiki kelemahannya. Dalam proses penyelenggaraan pendidikan di SMP, kemampuan manajerial kepala sekolah memiliki peranan penting untuk meningkatkan kinerja guru sebagai faktor kunci penentu keberhasilan mencapai tujuan pendidikan. Hasil analisis verifikatif membuktikan, kemampuan manajerial kepala sekolah baik langsung maupun tidak langsung berpengaruh positif terhadap kinerja guru, dengan total pengaruh sebesar 40,34\%. Dengan demikian dapat dijelaskan bahwa semakin baik kemampuan manajerial kepala sekolah maka kinerja guru SMP akan semakin baik.

Hasil analisis deskriptif menunjukkan bahwa budaya organisasi secara umum berada dalam kondisi yang kondusif. Namun masih terdapat kelemahan dalam aspek kenaikan gaji berdasarkan prestasi yang merupakan temuan empiris bagi budaya organisasi. Hasil ini dapat dijadikan petunjuk bagi kepala sekolah SMP, dalam mempertahankan kondisi budaya organisasi yang sudah baik dan berusaha meningkatkannya dengan memperbaiki kelemahannya. Hasil analisis verifikatif membuktikan, budaya organisasi baik langsung maupun tidak langsung berpengaruh positif terhadap kinerja guru, dengan besaran pengaruh 32,06\%. Dengan demikian dapat dijelaskan bahwa semakin kondusif budaya organisasi maka kinerja guru SMP akan semakin baik.

Dari hasil analisis jalur, kemampuan manajerial kepala sekolah dan budaya organisasi secara bersama berpengaruh positif dan signifikan terhadap kinerja guru dengan besaran pengaruh 72,40\%, selebihnya $27,60 \%$ dipengaruhi faktor lain yang tidak dimasukan ke dalam model.

Hasil analisis deskriptif menunjukkan bahwa kinerja guru dikategorikan tinggi, walaupun terdapat kelemahan pada aspek kemampuan guru dalam melibatkan siswa pada proses pembelajaran yang merupakan temuan empiris bagi variabel kinerja guru. Hasil ini akan memberikan petunjuk bagi guru untuk terus mempertahankan aspekaspek kinerja yang baik dan meningkatkannya dengan cara memperbaiki aspek yang lemah. Bagi kepala sekolah dapat dijadian bahan pertimbangan dalam mengambil keputusan untuk mempertahankan mutu lulusan SMP. Dari hasil analisis deskriptif, menurut persepsi responden kondisi mutu lulusan berada pada kondisi baik, tetapi masih terdapat kelemahan pada aspek penerapan nilai-nilai kebersamaan dalam kehidupan bermasyarakat, berbangsa, dan bernegara. Kemudian, hasil analisis verifikatif menunjukkan bahwa kinerja guru berpengaruh positif dan signifikan terhadap peningkatkan mutu lulusan SMP, dengan besaran pengaruh $81,00 \%$ selebihnya $19,00 \%$ dipengaruhi faktor lain yang tidak masuk ke dalam model. Selain itu diketahuhi bahwa besaran pengaruh kinerja guru terhadap mutu lulusan SMP $(81,00 \%)$ lebih besar dibandingkan dengan pengaruh kemampuan manajerial kepala sekolah dan budaya sekolah terhadap kinerja guru $(72,40 \%)$, hal ini berarti bahwa kinerja guru terbukti berperan sebagai variabel intervening. Hasil penelitian dapat menjelaskan bahwa semakin tinggi kadar kinerja guru, mutu lulusan SMP akan semakin meningkat.

\section{DAFTAR PUSTAKA}

As'ad, M, (2005), Psikologi Industri: Seri Sumber Daya Manusia, Yogjakarta: Liberty.

Atty Tri Juniarti dan Titien Sukartini (2014). Analisis Kompetensi Lulusan melalui Kinerja Guru di SMPN Wilayah III Cirebon" Jurnal Trikonomika,13(2), 145-152

Chomzanah, N dan Tedjasutisna A. (2001). Dasar-dasar Manajemen, Bandung: Amrico.

Danim, S. (2002). Visi Baru Manajemen Sekolah; Dari Unit Birkrasi ke Lembaga Akademik, Jakarta: Bumi Aksara.

Daryanto. (2001). Evaluasi Pendidikan, Jakarta : Rineka Cipta. 
Dharma, Surya. (2003). Manajemen Kinerja Falsafah Teori dan Penerapannya, Yogyakarta: Pustaka Pelajar.

Dessler, G. (2007). Manajemen Sumber Daya Manusia, Jilid 1, Jakarta: Erlangga.

Depdiknas. (2004). Pengembangan Perangkat Penilaian Kinerja Guru. Jakarta: Ditjen Dikti, Bagian Proyek P2TK.

Fattah, Nanang. (2005). Konsep Manajemen Berbasis Sekolah (MBS) dan Dewan Sekolah, Bandung: Bani Quraisy.

Febry Zakharia (2014). Pengaruh Budaya Organisasi dan Kepuasan Kerja Terhadap Kinerja Guru SMP Yadika 3 Tangerang" Jurnal Ilmu Ekonomi dan Sosial, 3(1),39 - 50

Handoko, Hani. (2003). Manajemen Personalia dan Sumber Daya Manusia. Yogyakarta: BPFE.

Handayaningrat, Soewarno. (2003). Pengantar Studi Ilmu Administrasi dan Manajemen, Jakarta: Gunung Agung.

Hofstede, G. (2003). Cultural Dimensions In Management And Planning. Asia Pacific Journal of Management January.

Idris, A R . (2005). Corporate Sosial Responsibility (CSR) Sebuah Gagasan dan Implementasi, Jakarta: -

Januar Barkah. (2014). Meningkatkan Kinerja Guru Melalui Kemampuan Manajerial Kepala Sekolah dan Iklim Organisasi di Madrasah" Jurnal SOSIO eKONS, 6(1).

Kusmianto. (2002). Panduan Penilaian Kinerja Guru, Jakarta: Kalam Mulia.

Mathis and Jackson. (2006). Human Resource Management Manajemen Sumber Daya Manusia,, Alih bahasa : Diana Anggelica, Jakarta: Salemba Empat.

Makawimbang, Jeery H. (2011). Supervisi dan Peningkatan Mutu Pendidikan, Bandung: Alfabeta.

Mangkunegara, A. P. (2004). Perencanaan dan Pengembangan Sumber Daya Manusia, Bandung: Refika Aditama.
Munandar, Ashar Sunyoto. (2001). Psikologi Industri dan Organisasi, Jakarta: Universitas Indonesia.

Mulyasa. (2003). Menjadi Kepala Sekolah Profesional, Bandung: Remaja Rosda Karya.

Muzakar (2014). Kinerja Kepala Sekolah dalam Meningkatkan Mutu Lulusan pada Madrasah Tsanawiyah Negeri Meureubo. Jurnal Ilmiah Islam Futura,14(1), 110-133.

Moeljono, Djokosantoso. (2006). Cultured Budaya Organisasi dalam Tantangan, Jakarta : PT Pustaka Binaman Pressindo.

Nazir, 2005. Metode Penelitian, Jakarta : Ghalia Indonesia.

Nafilatur Rohmah (2014). Keterampilan Manajerial Kepala Sekolah dalam Peningkatan Kinerja Guru (Studi Kasus di SMP Negeri 26 Surabaya)" Jurnal Inspirasi Manajemen Pendidikan, 4(4), 141-151

Nurul Mawaddatullin (2017). Pengaruh Kompetensi Manajerial Kepala Sekolah, Disiplin Kerja dan Motivasi Kerja Guru Terhadap Kinerja Guru di SDN Gugus II Kecamatan Kediri Kabupaten Lombok Barat" Jurnal Ilmiah Profesi Pendidikan, 2(1).

Ndraha, T. (2005). Budaya Organisasi, Jakarta : PT Rineka Cipta.

Permendiknas. No 13 Tahun 2007, tentang Standar Kepala Sekolah/Madrasah.

Permendiknas No 19 tahun 2005, tentang Standar Nasional Pendidikan.

Permendiknas No 23 Tahun 2006 tentang SKL

Permendiknas. No 12 Tahun 2007 tentang Penilaian Kinerja Guru.

Permendiknas RI Nomor 12 Tahun 2007, tentang Penilaian Kinerja Guru.

Pidarta, Made, (2004). Manajemen Pendidikan Indonesia, Cet. II, Jakarta, Rineka Cipta. 
Robbins, Stephen dan Mary coulter. 2008. Management, 8th Edition. By. Pearson Educational, NJ : Prentice Hall.

Robbins, Stephen P. (2005). Perilaku Organisasi, Alih Bahasa Benyamin Molan, Pearson Educational. Inc. Upper Saddle River, New Jersey.

\section{(2002). Teori Organi-}

sasi; Struktur, Desain, dan Aplikasi, Edisi , Jakarta: Arcan.

Riva'i, Veithzal. (2003). Kepemimpinan dan Perilaku Organisasi, Jakarta : Raja Grafindo Persada.

Sulistiyani A T dan Rosidah. (2003). Manajemen Sumber Daya Manusia, Yogyakarta: Graha Ilmu.

Sulistyorini. (2001). Hubungan antara Kemampuan Manajerial Kepala Sekolah dan Iklim Organisasi dengan Kinerja Guru, Jurnal Ilmiah Pendidikan,28(1), 00-00.

Supriadi, Dedi dan F. Jalal. (2006). Reformasi Pendidikan dalam Konteks Otonomi Daerah, Yogyakarta: Adicita Karya Nusa.

Suhana, Cucu. (2014). Konsep Strategi Pembelajaran, Bandung: PT Refika Aditama.

Sudjana. (2005). Penilaian Hasil Proses Belajar Mengajar, Bandung: Remaja Rosda Karya.

Siagian, Sondang.P. (2014). Manajemen Sumber Daya Manusia, Jakarta: Bumi Aksara.

Schein, E.H. (1990). Coming to a New Awareness of Organizational Culture. Sloan Management Review Winter.

Spencer, M.I.Lyie and Spencer, M. Signe. (1993). Competence at Work; Models for
Superior Performance, John Willy \& Son, Inc. New York, USA.

Topping, Peter A. (2002). Managerial Leadership; The McGraw-Hill Exe-cutive MBA Series, McGraw-Hill. New York Chicago San Francisco Lisbon London Madrid.

Undang-undang Nomor 20 Tahun 2003 tentang Sistem Pendidikan Nasional.

Undang-undang Nomor 14 Tahun 2005 tentang Guru dan Dosen.

Wahab. (2008). Anatomi Organisasi dan Kepemimpinan Pendidikan; Telaah Terhadap Organisasi dan Pengelolaan Organisasi Pendidikan, Bandung; Alfabeta.

Wahjosumidjo, (2005). Kepemimpinan Kepala Sekolah; Tinjauan Teoretik dan Permasalahannya, Jakarta : Raja Grafindo Persada.

Wartakotalive.com. (2015). Hasil Uji Kompetensi Guru Masih di Bawah Standar. Rabu, 30 Desember 2015. Diakses 16 Agustus 2018 Online_ tersedia.

Winkel, SJ. (1996). Psikologi Pendidikan dan Evaluasi Belajar, Jakarta: Gramedia. 
BIOGRAFI PENULIS

\begin{tabular}{|l|l||}
\hline & $\begin{array}{l}\text { Anedi, Alumni Program Studi Magister Ilmu Administrasi, Pascasarjana } \\
\text { Universitas Majalengka, Provinsi Jawa Barat, Indonesia. } \\
\text { Email: anedinedi@gmail.com }\end{array}$ \\
\hline
\end{tabular}

